\title{
Chapter 7. The Kalauna House of Secrets
}

\section{Michael W. Young}

The first government census patrol of the D'Entrecasteaux Islands in the Eastern Division of Papua was conducted in 1921, on foot and by boat, by a British officer named R.A. Vivian. He is commemorated in local legend as 'Misibibi', a colonial culture hero whose fantastic exploits, draconian laws and ruthless feats of social engineering have almost mythical status. He is credited with having transformed the social landscape, though I deduced that, on Goodenough Island at least, 'Misibibi' represents a telescoped series of government officers (Young 1971:31-32). One man alone could not possibly have done so much in so short a time that was so memorable - unless he was Ghengis Khan.

While Mr Vivian does not appear to have actually killed any of the people he travelled among (it would have been counterproductive for his census), he had the most virulent contempt for them. Contempt for their Papuan subjects was not uncommon among Resident Magistrates in the 1920s, but Mr Vivian was unusual for the skill with which he gave vent to it in the terse, schoolmasterly sarcasms of his patrol report (for example, 'I found it necessary to tell the people that dotting themselves over the landscape did not constitute a community'). Mr Vivian also expressed his contempt more directly by ordering the destruction of houses that were not up to his standards of adequacy. Disorder was his bane; unwholesome houses offended him deeply. His prejudices were confirmed in one Goodenough village where he had camped when a house with four occupants collapsed during the night. 'Nobody hurt but all shaken', he noted. 'This bears out my recent action in almost daily condemning ramshackle dwellings, very often bogus ones' (Vivian 1921).

What Vivian frequently referred to in his report as 'bogus houses' were the islanders' pathetic recourse to anti-colonial resistance. In an attempt to appease the all-powerful government (these islands had been pacified for a whole generation), yet to maintain their own preferred dwelling sites, people sometimes built false, dummy or 'bogus' houses on the 'healthier' (that is, more accessible) sites that they had been ordered to occupy. They only pretended to live in them, presumably once or twice a year when a government officer chanced to come by. It was these bogus houses in particular that Mr Vivian delighted in destroying.

As an ironic aside I might add that during World War II, when an immense airbase was constructed on the alluvial plain of northern Goodenough, Australian 
soldiers also built bogus houses, along with dummy gun emplacements and 'airplanes' made of painted sticks and paper. This elaborate exercise in deception was to fool Japanese spotter planes into reporting that the base was heavily armed and massively occupied.

The moral of this colonial tale is that houses in Goodenough Island may not be what they seem to be.

Architecturally, Goodenough houses (manua) were, and still are, very simple. The indigenous, pre-colonial design was described by Jenness and Ballantyne, writing of the early contact period of 1911-12:

All houses, save an occasional widow's hut or a shelter for storing food, are erected on four poles forked at the top to hold the plates ... Two plates run horizontally from the front to the back posts of the house, and from them a series of poles and rafters lead up and support the ridge-pole. Everything is firmly lashed together with vines ... Thus the frame-work for the house is provided; for walls it is covered with overlapping layers of sago-leaf matting laid horizontally. Back and front are sometimes closed in the same way, but often the matting is here replaced by planks on which the native can display his artistic powers. The back wall is unbroken, but a gap is left in the front by which the inmates can enter; it can be closed at will by native mats. A platform is often built in front, usually as a mere extension of the floor, though sometimes a foot or so lower. This makes it easier to enter the hut, and at the same time offers a very convenient place to sit and gossip, especially when the roofs and sides are made to project as well and so ward off both sun and rain. Propped up against the platform, or lying on the ground below the house, will be found the ladder, which is simply the stem of a small tree with notches cut for steps at intervals of a few inches. The floor is made of transverse poles or rough boards resting on the plates, and is generally covered with mats of coco-nut leaves. The interior is sometimes divided into an inner and outer compartment, with a gap in the dividing wall similar to that in the front of the house. In some houses there is a low bench running along one side, for one of the inmates to sleep on, but this is not very common.

All huts are built along these lines, though naturally there are slight differences in individual cases. The greatest variation, perhaps, is found in some of the larger huts, when the platform extends around one side and the door is made in one of the longer faces. A medium-sized hut that we measured had a front of 226 and a depth of 26 . The platform, which extended 6 outwards from the floor, was 5 above the ground, and the height of the room inside from floor to ridge-pole was only 48 . Sometimes a hut is first built upon the ground, then lifted entire and set 
in place upon its posts; more often it is built up directly on the posts (1920:182-183).

In Kalauna the old style of house is called manua mo'a ('real' or 'true' house). Jenness and Ballantyne (1920:43), who appear to have visited Kalauna in 1912, estimated there were 150 houses. A decade later Vivian recorded 392 people living there. In 1967 I counted between 120 and 130 houses, though the population was then 470. I mentioned the discrepancy between Jenness and Ballantyne's count and my own to some Kalauna men, and they immediately suggested that there might well have been more houses in their grandfathers' time because many more men were polygamous in those days and required a house for each wife, and because many men would then have had separate yam houses (bolu). ${ }^{1}$ Old men say that the manua mo'a houses kept out the rain better than the modern ones and lasted longer, probably because of the thicker thatch. They were warm and cosy, 'like a bird's nest', one man told me.

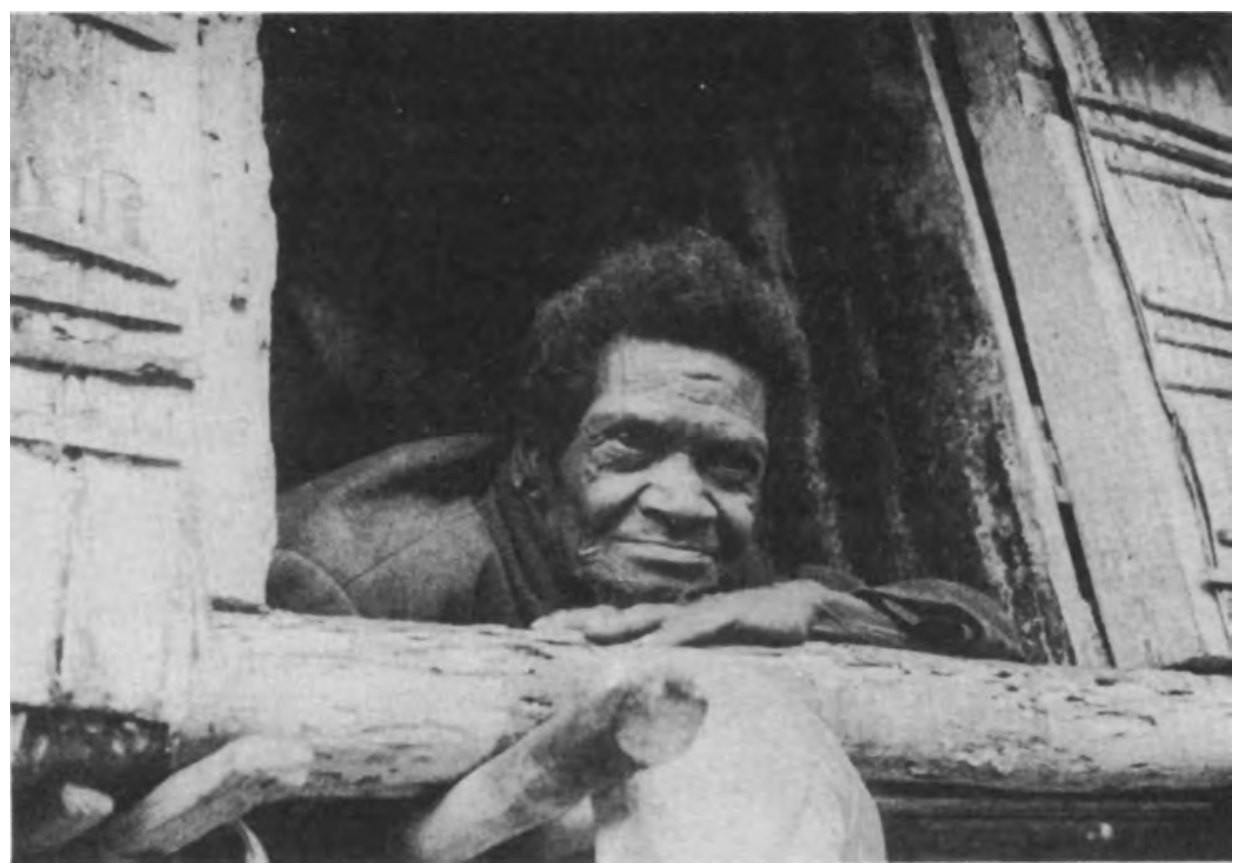

Figure 1. Kivina the architect, Kalauna 1968

An old man called Kivina taught many of his generation how to build in the modern style (see Figure 1). Others learnt from the Port Moresby region and on Misima Island, where men went to labour on copra plantations or in gold mines. When they returned to Kalauna, they experimented and pooled their new knowledge, but the new style was not adopted by everyone. It took a world war to make the new style fashionable in Kalauna and neighbouring villages. In 1942 the inhabitants of this area were evacuated to Fergusson Island, 
supposedly out of harm's way of anticipated Japanese airraids on the enormous allied airbase that was being constructed on the alluvial plain of Vivigani. Fergusson people, with government encouragement, had already adopted the new style of house. On their return to their own villages, Goodenough people began to build almost exclusively according to the new design, which they called manua barak after the 'barracks' or rest houses of patrolling government officers and their policemen.

The traditional design of manua mo'a had all but disappeared by the time of my first fieldwork in the late 1960s. Kalauna had only one such house, situated some distance from the main village, and although I photographed it, I neglected to measure it or inspect its construction before it was destroyed following the death of its owner's wife. ${ }^{2}$

Today houses in Kalauna are rectangular structures with an evenly gabled roof. The bush materials used are the same as before: walls of pandanus leaf or sago leaf mid-rib, floors of 'planks' of black palm or slats of areca palm, and roofs of woven sago leaves. Binding is still by means of the tough skin of a vine, though nails are also used, if available. Houses stand on piles 3 to 4 feet high and access is by a step or notched log through a single doorway. Small 'windows' or peepholes are cut in one or two of the walls. The houses of a hamlet are still clustered closely together, and most are less than 6 feet apart. Internally, houses are partitioned into two or more 'rooms', with a small annex sometimes forming a kitchen. Cooking is done on an open fire on a bed of sand and ashes, and vessels are supported by three hearth stones. A nuclear family usually sleeps together in the same room, and in a small house it is the one which is used to sit and eat in during the day.

A new Kalauna house with its walls of fresh and tightly-bound pandanus leaves looks like a large brown-paper parcel. In a matter of months the shiny brown walls fade to a dull fawn. After several years the sago roof turns black and threadbare and it leaks during rain; the floor slats become loose and treacherous. After about ten years the whole house may begin to tilt and fall apart.

House sites - rather than the impermanent houses themselves - are transmitted according to the normal rule of patrilineal inheritance: sons inherit the sites occupied during their father's lifetime, provided, that is, that they are in his natal (clan-owned) hamlet. Since deteriorating houses are replaced only over a period of several months, a man will build a new house on a different site to the old: perhaps closely adjacent to it, perhaps at the other end of the hamlet, perhaps in a new hamlet altogether. A house is usually abandoned once its owner has completed a new one. The old house is by that stage utterly derelict, having lost to the new dwelling its serviceable timbers, its nails and fittings, and even part of its black palm flooring. 
Kalauna's settlement pattern, based on strongly patrilocal agnatic groups, reveals a systolic-diastolic movement over time (Young 1983:265-268). Offshoot hamlets are periodically founded outside the main village, often in the yam gardens where temporary garden huts (vada) are erected. These huts may form the basis of proper houses (manua). When these houses begin to decay, their occupants return to the parent hamlet once more. A twenty-year time-exposure photograph of the village would show its rhythmic expansion and contraction as families moved to the periphery to found new hamlets, then shifted back to the centre again. In addition to its houses, one or two other man-made structures can be found in every hamlet; these are the tidy piles of stone slabs, the sitting circles (atuaha) of the owners. They provide, far more so than do perishable houses, permanent lithic symbols of group identity and patrilineal continuity (Young 1971:22-24). To sit without invitation upon another's atuaha is a breach of good manners, though not as unforgivable as to enter a house without the owner's permission.

After the defeat of Japan the departing Australian army left behind a wealth of building material, and, even twenty-five years later, corrugated iron and 'marsden matting' were still being used in the construction of houses in eastern Goodenough. Typically, angled pieces of corrugated iron were placed along the apex of a roof; this both weighed down the sago thatch and sealed the ridge. Doors could also be fashioned easily from sheets of iron. The large heavy strips of 'marsden matting' (used by the soldiers to build bridges as well as to serve as airstrip matting) were used by villagers for pig fences and, when laid upon 44-gallon drums, they made admirable yam platforms for food exchanges. The same drums were in common use as house steps, and their severed tops, with three hearth stones set upon them, were still serving as fire trays in the kitchens of Kalauna as late as 1980. Heavy duty wire mesh (inexplicably called 'tiger wire' in Kalauna) makes an effective barbeque grill.

The new house design was approved by the colonial government, since it was believed to be an improvement on what were regarded as small, dark, pokey, flimsy and unhygienic dwellings. Although the houses that replaced them in Kalauna were lighter and possibly more hygienic, they were often also small, pokey and flimsy. (I have slept in houses that reminded me of Alice in Wonderland: with my head firmly against the back wall, my feet jutting into the 'kitchen', and every turn in my sleep shaking the entire house.) Few houses in Kalauna have more than two rooms, and since adolescent children often move out of the family home, there is no need for more than a single bedroom for a couple and their young children. Those adolescents who do remain make do with the kitchen-cum-dining room, and at night simply unroll their sleeping mats on the floor wherever there is space. 
'Bachelor houses' (manua tubulakata), occupied by two or three adolescent boys, tend to be even smaller, flimsier (and with something like bravado) higher off the ground than the ordinary 'family' house. They resemble small tents on stilts. Since the boys do not cook for themselves but eat with their parents or married brothers (though they are expected to provision the hearths they eat at with food from their own gardens), the youths' houses can afford to be smaller, and they usually consist of one all-purpose room. They are singularly bereft of furnishings.

Furniture is minimal in a Kalauna house. In the 1960s one invariably sat on the floor (crisp new pandanus mats are always unrolled for visitors to sit upon); in the early 1980s there were a few chairs and tables to be found, usually hand-made by ill-equipped local 'carpenters'. Such chairs were precarious and often bedbug-ridden, so one's comfort was better served by declining them. Unless there was a chair or two, of course, a table was pointless; so Kalauna men who aspired to own a table had first to consider acquiring chairs. But I noted that people who did own tables and chairs rarely used them inside the house, since it was too small to accommodate them comfortably. For the same reason beds were also a rarity, though they are becoming more common in the present decade; again, a house owner would have to think about whether he wanted to build a bed before he planned his house.

So what do Kalauna houses house if not furniture? People certainly (nuclear families usually), but also their portable possessions, including tools, heirlooms, yams and, perhaps most important of all, magical paraphernalia.

The most remarkable thing - perhaps the only remarkable thing — about houses in Kalauna is the secrets they contain. I do not mean the personal or family secrets of their occupants (though of course they harbour their share of those), but rather the magical secrets of their owners.

A word first about magic and secrecy. With the unique exception of land, the most important heritable property in Kalauna is magic. This is so largely because its many kinds are held exclusively. Magic that is known to all is of no value; it is merely folklore (Young 1971:67). To Kalauna men magic is by definition something of intrinsic value; exclusive, secret and to be protected from appropriation by others. One's magic is one's skill for living, one's advantage in the endless skirmishes for status in an egalitarian but competitive milieu. I have elsewhere described this ethos of secrecy and the value of the hidden' in the following terms:

When power is disguised and value is concealed, dissimulation becomes a way of life. That one does not know another's mind is a Melanesian axiom; that Papuans have white skins beneath their brown ones is common belief. The inside of a fruit, a tuber, a person, a house, a basket, 
a tree, a mountain or a stone is where the true value of these things is to be found. Humanity itself came from inside the earth, emerging from a hole at the top of a mountain. Sorcerers and magicians contain their secret powers in bundles kept in baskets hung in dark recesses of their roofs. Everyone keeps their valuables in boxes or baskets likewise hidden away in their houses. To be 'showy' is a prerogative of rank - a transient attribute at best, temporarily accorded to feast-givers - or the privilege of marriageable youth. Display (of self, of wealth, of beauty) has its place, but the normal state of affairs is concealment, a studied modesty, and a cultivated shabbiness. There is a disregard for appearances, an indifference to aesthetics. But this belies the inward state. The diffidence is a cultural affectation, a display of non-display. That it is motivated is evident from the occasions when display is enjoined: at feasts, distributions, marriages, mortuary ceremonies, canoelaunchings and other inaugural occasions. Then men and women paint their faces, rub their skins with coconut oil, decorate their hair with the brightest flowers and feathers, adorn their limbs with scented leaves and shell valuables. To an outsider, the effect is dry land blooming after rain; the visual shock of the sudden flowering is all the greater for the unpromising aridity of the usual condition. People are revealed as aesthetes after all, beautiful beneath the skin (Young 1987:249-250).

Interiority is synonymous with secrecy, and both are synonymous with magic. Indeed, English 'secret' (sikeleti) has passed into the vernacular as a generic term for magic. Indigenously the closest to a generic term was yiba, though strictly speaking this refers to the material paraphernalia or 'stuff' of magic: small stones, dried roots or plants, greenstone axe heads, bone relics, red ocre, ancient limesticks, the teeth of dogs and flying foxes, and many other things worthy of a medieval alchemist. Yiba, then, is used metonymically. There were generic terms also for the various classes of magic: for love, for war, for the infliction of illness, for weather, for crops, for controlling hunger, and so forth. All of these varieties of magic, which are believed to control human destinies, have their associated paraphernalia or yiba.

The house, manua, is thus the repository of its owner's magical paraphernalia, just as the owner's mind, nua (variously located in the skull or the belly), is the repository of his magical incantations (kweli). The lexical correspondence of manua and nua is doubtless coincidental (nua is not the root of manua), but this does not prevent one from appreciating the pun of the conceptual complementarity given by the formula:

\begin{tabular}{|c|c|c|c|c|}
\hline nua & kweli & $::$ & manua & yiba \\
\hline mind & spell & $::$ & house & paraphernalia \\
\hline
\end{tabular}


In other words, the house contains the material appurtenances of the human mind's magical knowledge. Fancifully, insofar as it contains the tools of his trade, the Kalauna magician's house might be likened to the Western scholar's library of rare and valuable books.

The typical Kalauna house shape, traditional or modern, signifies nothing but itself. It does not imitate, reflect or resemble a boat, a canoe, a temple, or even a human body. Insofar as the house is a symbol, therefore, it is basic and underivative, like the Platonic 'house' which a Western child draws (typically on a smaller scale to Mummy and Daddy). Neither are the named, constituent parts of the Kalauna house metaphors of other structures, and they do not reflect other symbolic domains. The Kalauna house has no particular orientation, no symbolically salient 'sides' or halves, no interior demarcations which the sexes must observe, and no conceptually significant oppositions such as above and below, high and low.

In short, the social space encompassed by the house is relatively unmarked and undifferentiated. ${ }^{3}$ Nevertheless, the house's interior (vetawana) is symbolically salient in itself: as concealed interiority, a domain of nafone, 'inside' or 'within-ness'.

As a social space, then, the house's interior is its most important feature. It contains, minimally, a cooking hearth, a storage area for yams, and a shelf or platform (ubudoka) in the roof at the back of the house (usually above the 'bedroom'). The shelf or platform is typically the place for the secrets: the locked boxes containing shell valuables and other heirlooms; the baskets containing bone relics, yam stones and the paraphernalia (yiba) of magic and sorcery, all placed well out of the way of children's questing fingers and visitors' prying eyes.

Among the secrets of any house in Kalauna are fist-sized black stones that lie in some dark recess. A man bequeaths to his married sons one or more such stones. They are 'inhabited' by ancestral spirits, inainala, which guard the house and protect its contents from theft. Inainala are the undifferentiated spirits of dead patrilineal ancestors, and a Kalauna man would be hard put to say which particular ancestor dwelt in which particular stone. (Some say that certain key components of the house - the ridge-pole, and even the walls - may be 'occupied' by inainala too.)

What matters is the pragmatic belief that the stones 'protect' the house, rather like a burglar alarm, or more accurately perhaps, a couple of guard dogs. Unauthorized persons entering the premises (as our own warning notices have it) are at risk of being 'hit' by the inainala associated with the stones. To be 'hit' (kwava) by a spirit means either to be physically struck down (people literally fall out of houses) or to become crazed, deranged and even run amok. Typically, a man who is kwava behaves like one posssessed, and some people entertain the 
vague belief that the striking inainala does enter the victim's body. The victim can be cured most readily by the house owner himself, who bids the inainala leave the intruder alone. When strangers are invited to enter a house the owner should announce them by name to reassure the inainala that their presence is no threat. It occasionally happens that even friends and distant kinsmen are struck when they enter a house; they suffer nightmares, delirium or worse, and deduce that the guardian inainala had not recognized them. So one approaches unfamiliar houses warily — rather as if savage dogs were kept inside. The presumption that dwelling houses contain their owners' inainala spirits is the only sense in which Kalauna people believe that houses are animated or 'alive'.

Despite the fact that the house doorway (awana) also means 'mouth', and that windows are called 'eyes' (matana), the house as an analogy of the human body is not systematically developed. I once tried to get my Kalauna friends to concede that the back of the house where yams are stored was 'like' the human belly (kamona). They were perplexed. For a start, they pointed out, the vetawana is the place of sisikwana, the magic of appetite suppression. 'Yes', I urged, 'like the belly!'. But, they reminded me, the whole purpose of sisikwana is to permit lokona (prestigeous abstention). Now the human belly, on the other hand, is precisely the place where they do not want their yams to go, for to consume them is to waste them! So my literalism was defeated by their more devious logic of secret sisikwana in the service of food conservation and the prestige of the tolokona, the man-who-abstains.

A big-man's house is generally no larger than anyone else's; the size of the man is not indicated by the size of his house. Sometimes quite the contrary, for Kalauna leaders play a dissimulating game of affected humility. They wear old clothes. They deny their gardens are big; they keep their pig herds small. They practise penury quite deliberately to avoid the charge of yakaikai (hubris) or kasisi (swank or showiness), both of which imply an unseemly pride that challenges the social worth of others. The egalitarian ethos justifies resentment of such behaviour and instigates sorcery attacks or accusations to cut the ostentatious down to size.

Traditionally, it was the custom for a big-man to deflect personal status onto his eldest son and heir by building him a more imposing house than his own. It would serve as a dwelling for the unmarried youths (tubulakata) of the hamlet. More importantly, however, it would serve as a repository for crop wealth. The manua tubulakata would be painted with the clan or sub-clan design (naba), and inside the house the centrepost would be specially doctored with powerful sisikwana magic to 'guard' and preserve the largest yams of the hamlet. That is to say, the men of the clan or sub-clan would, on their leader's instruction, put their biggest and best yams in the manua tubulakata, arranging them neatly around the centrepost. There they would stay, the secret pride of the hamlet, 
until they hardened and rotted or were given away coercively in competitive exchange (abutu). The magic was believed to make them inedible, even poisonous. So strong was this sisikwana that women and children were forbidden to enter the house. (It is due to this inconvenience, this danger, that men say they discontinued the practice of building naba-decorated boys' houses.) Sisikwana is believed to stunt a child's growth and dry up the milk of a lactating woman; it can even render her infertile. Sisikwana represents a principle of self-denial and abstention, as manifested in shrunken stomachs and shrivelled yams, and it is therefore antithetical to sex, fecundity and growth.

The most important set of rituals in Kalauna is sometimes loosely referred to as 'big' sisikwana. This ceremony is performed periodically by the magicians of the dominant clan of Lulauvile, the toitavealata or 'guardians' of the village. The ceremony concerns communal prosperity and is called manumanua, a reduplication of the word for house. Figuratively manua can also mean 'clan' or 'village', hence manumanua can be glossed as 'staying at home' or 'remaining in the village'. Indeed, sitting still is a performative act of the magicians who conduct manumanua: the ceremony which is designed to banish famine and anchor food in the community. In its broadest sense manumanua refers to any rite (or myth) concerned with creating or maintaining prosperity.

I have described manumanua at length elsewhere (Young 1983), so I say little about it here except to stress that the symbolic weight it derives from manua, house, is precisely that of something fixed, secured or anchored. With the occasional exception of special feasting platforms (which are also magically 'anchored'), the house represents the largest and most solid, the most static and immovable manufactured object within the competence of local technology. ${ }^{4}$

The fact that the house is a human creation is also important, for Kalauna people believe their creations to be vitalized by ancestral powers (inainala) of their own, human, kind: kaliva mo'a ('real people'). Large trees and rocks, on the other hand, although seemingly symbolically apt for the purposes of manumanua, are more ambiguously animated by non-ancestral spirits, tubuvagata ('eternal ones'). It would be inappropriate and even dangerous to attempt to summon their powers. In the manumanua ceremonies the static or immobile properties of the house are magically transfered to garden produce, and both people and their crops are ritually enjoined to stay, to remain in place. Conversely, manumanua ritually countermands the 'wandering' (of both people and crops) associated with famine. Thus does 'house', redolent of hearth and home fixed in space, symbolize the dominant idea of manumanua.

There is another form of magic, called bakibaki, which increases the stasis of the house and induces contentment in its occupants. When a new house is built, certain leaves (and sometimes a small stone) are bespelled and placed at the bottom of one of the post holes. Bakibaki may also be performed by rubbing the 
post itself before it is planted in the ground. This magic is intended not only to 'anchor' the house in the hamlet but to keep its occupants dwelling there, by making them homesick whenever they leave it. Bakibaki is thus a quotidian complement to manumanua in that it promotes 'sitting still' and discourages 'wandering'. This anchoring magic is also performed whenever a new stone sitting circle (atuaha) is built; in this instance a ritual specialist places the bespelled leaves (or stone) beneath the main backrest of the circle.

It is to be expected, given this scheme of values, that the housepost particularly the owola, or centrepost - is a symbol of anchored strength and endurance. The centrepost is a synecdoche of the house, as the big-man is a synecdoche of his hamlet. Hence, the centrepost is to the house as the leader is to his hamlet or clan. Lulauvile men also argue that since their leaders - the toitavealata - 'guard' and 'look after' the entire community, they are entitled to be regarded as the owola of the village: in English idiom, too, we speak of 'the pillars of the community'.

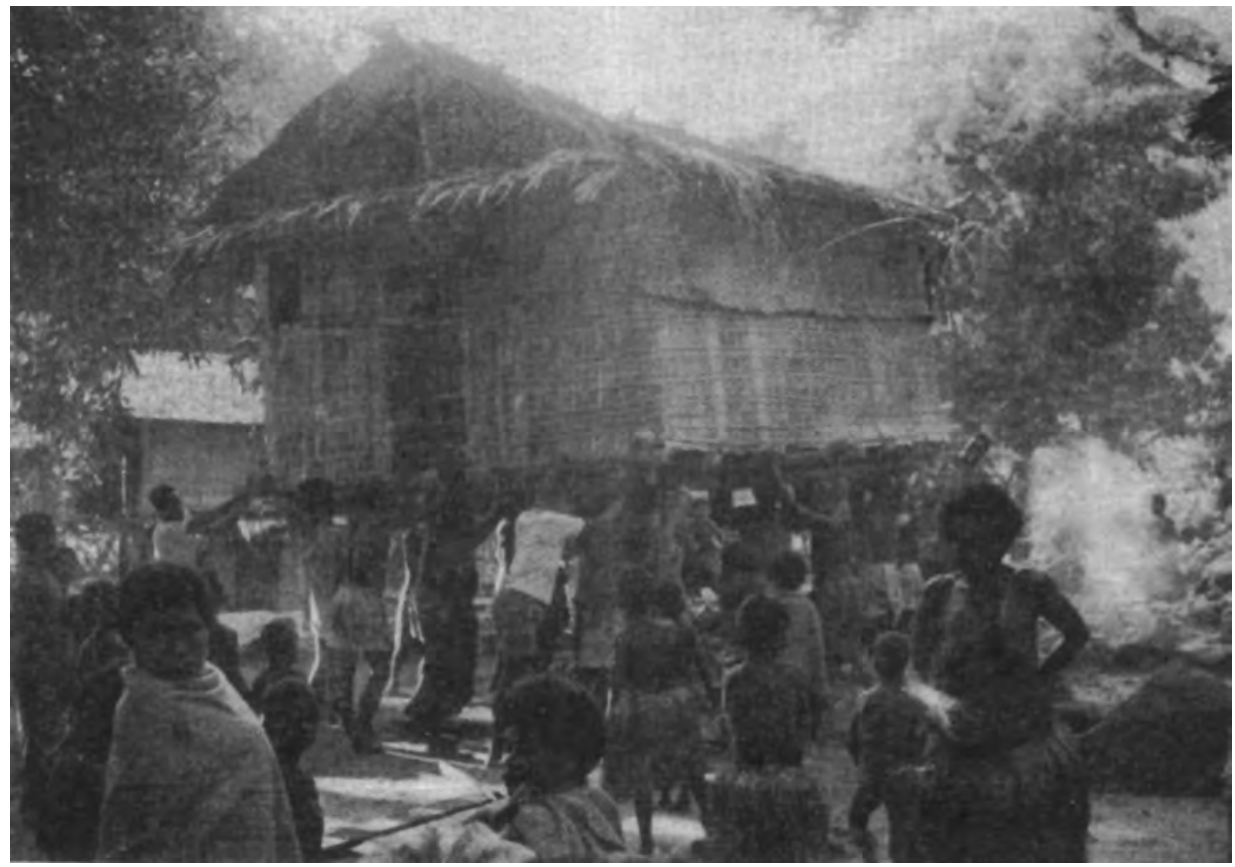

Figure 2. Moving house in Kalauna 1968

I might add that Lulauvile clan used to be known as manua u'una, the 'head' or ruling 'house'. Its traditional naba design, as I have described elsewhere (1983:266-267), is based on a zigzag motif which symbolizes the mythical snake-man hero, Honoyeta. Lulauvile's most awesome magical secrets are concerned with the control of the sun through stones and spells bequeathed by Honoyeta. (One of the Lulauvile magicians had a special hole in the roof of his 
house through which the sun's rays entered to warm his sunstone, and it was believed to be within his power to activate drought at any time. People were understandably wary of displeasing him.)

Every house has an exterior and an interior, and in many societies the exterior of a dwelling is an important indication of the status of its owner(s). I have argued here that in Kalauna it is the interior of the house that is more important (another blow to Western visualism?). Traditionally, it is true, some exterior house-boards in Kalauna were painted with esoteric clan or sub-clan designs (naba), which non-owners copied on pain of illness or death. Such designs were a visual clue to the owner's identity and the range of his magical competences. But as I have also noted, it was more usual for a leader's unmarried son to display the naba on the front of his bachelor house. Nowadays naba decorations have disappeared entirely and the great majority of Kalauna houses are drably undistinguished and uniformly anonymous. The meanest hovel may be occupied by the most respected leader or the most highly ranked magician. But it is what he keeps inside his house that signifies his reputation.

The dissemblance of power is a fine art in the ostensibly egalitarian society of Kalauna. Insofar as the house is a site of concealment and the innermost locus of secrets, it represents, too, the principle of least exposure by which power is disguised in Kalauna. This principle is the very antithesis of the principle of simulated aggrandizement manifested in large façades, in bogus houses with empty interiors - the very buildings, in fact, erected by Australian soldiers in 1942 to bluff the Japanese.

\section{References}

Jenness, D. and Ballantyne, A.

1920 The northern D'Entrecasteaux. Oxford: Clarendon Press.

Vivian, R.A.

1921 Report of a census patrol to Goodenough Island. Canberra: Commonwealth Archives.

Young, Michael W.

1971 Fighting with food: leadership, values and social control in a Massim society. Cambridge: Cambridge University Press.

1983 Magicians of manumanua: living myth in Kalauna. Berkeley: University of California Press.

1987 The tusk, the flute and the serpent: disguise and revelation in Goodenough mythology. In Marilyn Strathern (ed.) Dealing with inequality: analysing gender relations in Melanesia and beyond, pp.229-254. Cambridge: Cambridge University Press. 


\section{Notes}

1 Jenness and Ballantyne worked on the assumption that the houses contained on average only two or three occupants. The average is higher than that today: between three and four was my estimate in 1967. These early authors also acknowledged that house counts were an unreliable guide to population numbers:

Usually there are one or two ruinous uninhabited structures in each hamlet, since it is customary, when an inmate dies, for the rest of the family to abandon their old home and build a new house close by. It is, therefore, impossible to estimate from the number of houses the approximate population of any hamlet, unless one first inquires as to the number of the houses that are uninhabited (1920:47).

2 On my most recent visit to Kalauna (June 1989) I was surprised to find three houses of the old design. Their owners said they had built them with the express purpose of preserving the knowledge of their construction, 'so that the custom would not be lost'. The newest and best of these houses was built by a classificatory son of Kivina, from whom he learnt the technique. It was too small to live in, however, and resembled a yam house in size (12 foot long, 5 foot wide and 7 foot high). The owner was using it as a store house for his clay pots, tools and yam seeds, and for sitting in during the heat of the day. The pleasing visual lines of the superstructure were starkly incongruous with the four squat and rusty 44-gallon drums on which it sat. This did not trouble the owner; he said he would not bother to replace them with wooden posts.

3 This is just as well in view of its physically cramped dimensions; if as Douglas Lewis has said, the Tana Ai house is 'a machine for the suppression of time', the Kalauna house is for me a machine for the suppression of space.

4 Notwithstanding the notion of stasis associated with the concept manua, houses are sometimes moved lock, stock and barrel. A large group of men lift it bodily off its posts and carry it to another part of the village (see Figure 2), where they set it down on another set of posts. (See also plate 4 in Young 1971, showing men of Mulina clan shouldering a medium-sized house down an incline. They were bringing it from a garden site into the village.) 



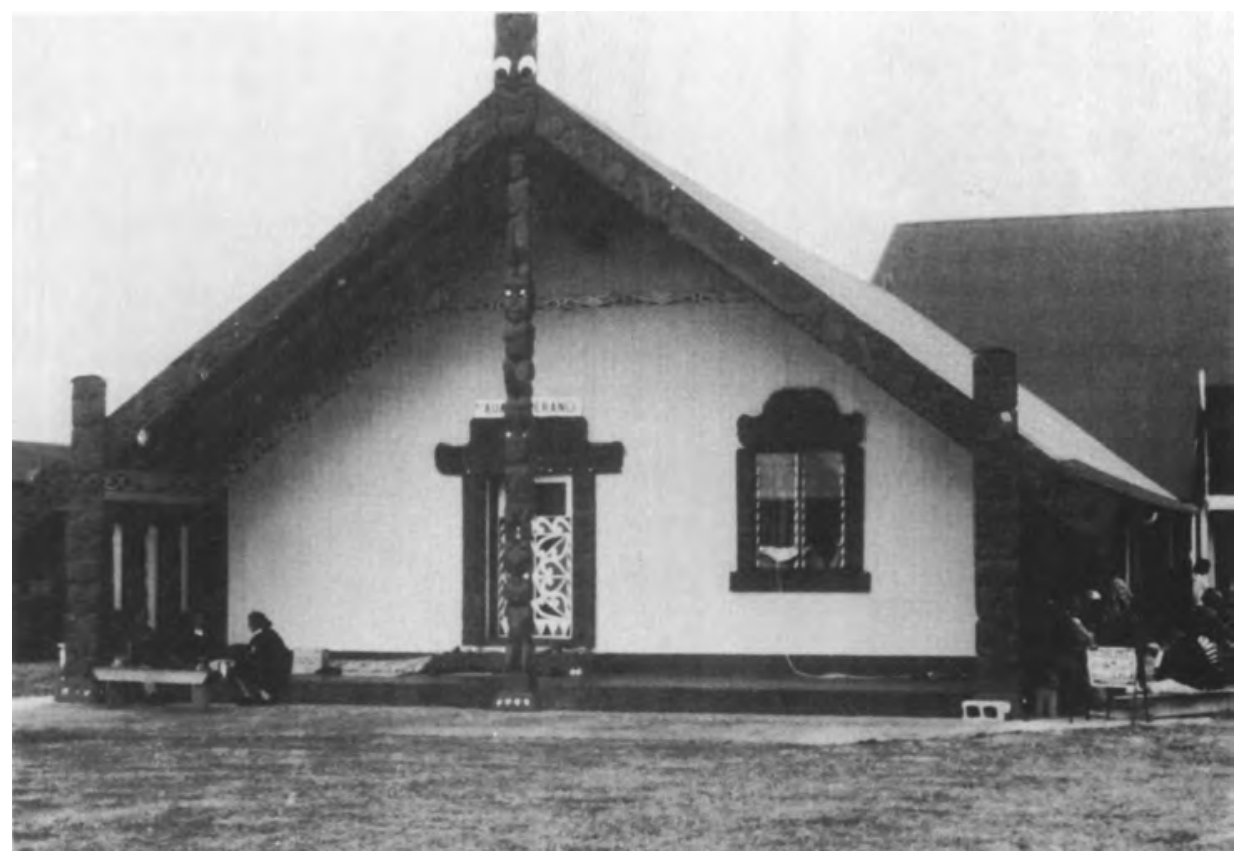

A view of the meeting-house at Maketu Marae, Kawhia 